\title{
A Study of the Sugarcane Yellow Leaf Disease in Argentina
}

\begin{abstract}
R. P. Bertani and M. F. Perera, Estación Experimental Agroindustrial Obispo Colombres (EEAOC)-Consejo Nacional de Investigaciones Científicas y Técnicas (CONICET), Instituto de Tecnología Agroindustrial del Noroeste Argentino (ITANOA), C.P. T4101XAC, Las Talitas, Tucumán, R. Argentina; M. E. Arias, Facultad de Ciencias Naturales e Instituto Miguel Lillo, Universidad Nacional de Tucumán (UNT), Miguel Lillo 205, C.P. 4000 San Miguel de Tucumán, Tucumán, Argentina; and Facultad de Ciencias Exactas y Naturales, Universidad Nacional de Catamarca (UNCa), Belgrano 300, C.P. 4700, San Fernando del Valle de Catamarca, Catamarca, Argentina; C. Luque, Facultad de Ciencias Naturales e Instituto Miguel Lillo, UNT; and C. Funes, V. González, M. I. Cuenya, L. D. Ploper, B. Welin, and A. P. Castagnaro, EEAOC-CONICET, ITANOA, Argentina
\end{abstract}

\begin{abstract}
Bertani, R. P., Perera, M. F., Arias, M. E., Luque, C., Funes, C., González, V., Cuenya, M. I., Ploper, L. D., Welin, B., and Castagnaro, A. P. 2014. A study of the sugarcane yellow leaf disease in Argentina. Plant Dis. 98:1036-1042.

Yellow leaf disease, caused by Sugarcane yellow leaf virus (SCYLV), is widespread around the world but very little information is available on this viral disease in Argentina. Therefore, the aims of the study were to assess the presence of SCYLV, analyze its distribution in the main sugarcane production areas of Argentina, characterize the virus, and determine histological alterations caused by its presence. For this purpose, 148 sugarcane samples with and without symptoms were collected in 2011 and 2012 from the province of Tucumán. One additional sample was collected in Salta, a different geographical, agroecological, and producing region. Results showed that SCYLV is widely distrib-

uted in commercial varieties of sugarcane throughout Tucumán in both symptomatic and asymptomatic leaves. A low but statistically significant positive correlation with virus detection and disease symptoms was found. BRA-PER was the only genotype detected by reverse-transcription polymerase chain reaction and sequence analysis of the SCYLV capsid protein gene. SCYLV-positive samples showed high starch levels in bundle sheath cells, whereas the asymptomatic ones, probably in an early stage of infection, were found to contain more chloroplasts. Symptomatic noninfected samples presented crystal formation probably associated with phytoplasma infection.
\end{abstract}

Sugarcane yellow leaf syndrome (SCYLS) was first reported in Hawaii in the late 1980s (39) and was subsequently observed in numerous other countries $(30,32)$. The typical symptom of the disease is an intense yellowing of the mature leaf midrib on the abaxial surface that generally occurs while the lamina is still green. In an advanced stage of the disease, a tissue necrosis that starts in the leaf tip and progresses toward the base may take place. In addition, leaves may show a red coloration of the midrib on the adaxial surface $(2,22)$. These characteristic symptoms, however, might only appear when the plant is stressed (2). It must be pointed out that most of these symptoms may only be related to other biotic or abiotic factors such as stress conditions, insect damage, water deficit, and cool winters, a situation that complicates a correct visual diagnosis (30).

The etiology of the yellow leaf syndrome has been controversial because the causal agent of the syndrome may be either a virus transmitted by aphids, Sugarcane yellow leaf virus (SCYLV) (39), or the Sugarcane yellow leaf phytoplasma (SCYLP) $(13,14)$ transmitted by leafhoppers. In addition, not only do they cause identical symptoms but also both pathogens can be detected in plants without disease symptoms (23). Recently, in order to differentiate between diseases caused by the virus and phytoplasma, the International Society of Sugar Cane Technologists (ISSCT) pathology committee approved the name "yellow leaf" (YL) for

Corresponding author: A. P. Castagnaro, E-mail: atilio@eeaoc.org.ar

R. P. Bertani and M. F. Perera contributed equally to this article.

Accepted for publication 12 February 2014.

http://dx.doi.org/10.1094/PDIS-12-13-1251-RE

(c) 2014 The American Phytopathological Society the disease caused by the virus and "leaf yellows" (LY) for the one caused by the phytoplasma (36).

SCYLV, an emerging virus that evolved from recombination events between ancestors of three different genera, is a member of the virus family Luteoviridae and belongs to the genus Polerovirus $(32,39,42)$. SCYLV resides in the phloem tissue of plants and is transmitted during vegetative propagation of sugarcane by planting infected cuttings (2). Infection by SCYLV causes alterations in chlorophyll synthesis, ruptures in the structure and function of chloroplasts (21), and disorders in the plant carbohydrate metabolism (29), which could have a direct impact on sugar accumulation in the plant (39). SCYLV is transmitted by the aphid vectors Melanaphis sacchari, Rhopalosiphum maidis, and $R$. rufiabdominalis in a persistent, circulative, and nonreplicative manner (37). Serological methods were the first techniques used to diagnose the presence of SCYLV but, in recent years, more sophisticated reverse-transcription polymerase chain reaction (RT-PCR) techniques have been developed to detect the presence of the virus $(9,10)$. Based on phylogenetic analysis of sequences of the entire or partial genome, SCYLV has proved to be a variable virus. Seven different genotype groups, based on where they were first described-BRA (Brazil), CUB (Cuba), PER (Peru), REU (Reunion Island), IND (India), CHN1 (China), and HAW (Hawaii)- have been reported $(1,2,16,25,41,42)$.

In Argentina, sugarcane production occurs in three regions: Northern (Salta and Jujuy Provinces), Littoral (Santa Fe and Misiones Provinces), and Tucumán Province, which is the main producer, contributing $70 \%$ of the total production (19). YL symptoms were first detected in sugarcane production fields in Tucumán in 1998 by Ramallo and Ploper (35); however, the authors could not confirm the presence of SCYLV by serology or molecular tests. Moonan and Mirkov (32) found SCYLV in one sample collected from a noncommercial sugarcane variety in the northern part of Argentina, and reported the coat protein (CP) gene sequence of an 
SCYLV from Argentina. More recently, Cafrune et al. (7), in a brief communication, identified SCYLV belonging to the BRAPER genotype, using the RT-PCR technique when analyzing leaves from canes showing disease symptoms in Argentina. However, the incidence and distribution of the disease in Argentina and Tucumán is still not clear, because there were only a few reports with little available information on monitoring, sampling methods, location, number of samples, and sugarcane genotypes tested.

The aims of this study were to (i) assess the presence, especially in commercial varieties, and analyze the distribution of SCYLV in the main sugarcane production area in Argentina (Tucumán Province) by surveying plants with and without symptoms during two consecutive years; (ii) characterize the virus in infected samples; and (iii) determine histological alterations caused by the SCYLV presence.

\section{Materials and Methods}

Plant materials. In all, 149 sugarcane leaf samples +1 (the first leaf from top to bottom of the stalk with clearly visible dewlap) were collected in the 2011 and 2012 growing seasons. Fifty-six samples with and without SCYLS symptoms were collected from April through June 2011 from commercial varieties, advanced breeding clones at final testing stages of selection, and parents used at the Estación Experimental Agroindustrial Obispo Colombres (EEAOC) Sugarcane Breeding Program, at 28 locations in Tucumán, Argentina (Table 1). In addition, 90 sugarcane leaf samples were collected from April through July 2012, from 10 advanced breeding clones at the final testing stage of selection and 5 commercial cultivars, at six different agroecological locations in Tucumán, Argentina where the local breeding program is maintained (Table 2). Three additional symptomatic samples from commercial sugarcane genotypes TUC 89-28, LCP 85-384, and NA 02-2320 were collected in the provinces of Tucumán (Las Talitas and Fronterita localities) and Salta (Tabacal locality), Argentina, respectively (Table 3). It must be pointed out that the last sample was included because Salta is considered to be a different geographical, agroecological, and producing area. Stan- dard agronomic practices for sugarcane production had been used in all the fields where samples were collected. Two leaves per sample were stored at $-70^{\circ} \mathrm{C}$ until extraction of the total plant nucleic acid.

Total plant nucleic acid extraction, RT-PCR to detect SCYLV with generic primers, and correlation between symptoms and presence of SCYLV. Frozen lamina tissue (approximately $200 \mathrm{mg}$ ) was placed in liquid nitrogen and ground in a mortar. Total nucleic acids were extracted using the protocol described by Aljanabi et al. (3). A specific SCYLV genome fragment from the $\mathrm{CP}$ coding region was amplified by RT-PCR using the virusspecific primers YLS111 (forward; 5'-TCT CAC TTT CAC GGT TGA CG-3') and YLS462 (reverse; 5'-GTC TCC ATT CCC TTT GTA CAG C-3') (M. Irey, unpublished data). The RT-PCR reaction was performed as described by Comstock et al. (11), with modifications. First-strand cDNA (4.5- $\mu$ l final volume) was synthesized using $2 \mu \mathrm{l}$ of total plant nucleic acid and $10 \mu \mathrm{M}$ reverse primer as the initial primer. The mixture was boiled at $95^{\circ} \mathrm{C}$ for $5 \mathrm{~min}$ and then quenched on ice for $3 \mathrm{~min}$. RT solution consisting of $1 \times \mathrm{RT}$ PCR buffer, $100 \mu \mathrm{M}$ dNTPs (Amersham Biosciences), $1.3 \mathrm{U}$ of RNase inhibitor (Promega Corp.), and $13 \mathrm{U}$ of M-MLV (Promega Corp.) was performed at $42^{\circ} \mathrm{C}$ for $30 \mathrm{~min}$. Amplification was carried out in a $20-\mu \mathrm{l}$ reaction mix consisting of $7.5 \mu \mathrm{l}$ of RT reaction solution, 1× PCR buffer (Promega Corp.), $1.5 \mathrm{mM} \mathrm{MgCl}_{2}$ (Promega Corp.), $25 \mu \mathrm{M}$ dNTPs (Amersham Biosciences), $1 \mu \mathrm{M}$ forward primer $(60 \mu \mathrm{M}), 0.1 \mathrm{U}$ of Taq DNA polymerase (Promega Corp.), and diethylpyrocarbonate (DEPC) water (USB Corp.) to final volume. PCR cycling parameters were 1 cycle at $95^{\circ} \mathrm{C}(5$ $\mathrm{min}), 54^{\circ} \mathrm{C}(1 \mathrm{~min}), 72^{\circ} \mathrm{C}(10 \mathrm{~min})$, and $94^{\circ} \mathrm{C}(1 \mathrm{~min}) ; 40$ cycles at $94^{\circ} \mathrm{C}(15 \mathrm{~s}), 54^{\circ} \mathrm{C}(15 \mathrm{~s})$, and $72^{\circ} \mathrm{C}(30 \mathrm{~s})$; and a final elongation at $72^{\circ} \mathrm{C}$ for $5 \mathrm{~min}$. The RT-PCR product was analyzed by electrophoresis through a $1.5 \%$ agarose gel in Tris-acetate-EDTA buffer, stained with ethidium bromide, and visualized under UV light. The size of the fragment amplified from infected leaves was $350 \mathrm{bp}$.

Phi coefficient was calculated in order to correlate the presence or the absence of symptoms with positive and negative SCYLV samples by RT-PCR.

Table 1. Sugarcane yellow leaf virus in leaf samples of diverse sugarcane genotypes sampled in 2011, from various locations in Tucumán province, Argentina

\begin{tabular}{|c|c|c|}
\hline Symptoms, virus ${ }^{\mathrm{a}}$ & Samples $^{b}$ & Location $^{\mathrm{c}}$ \\
\hline \multicolumn{3}{|l|}{ Asymptomatic } \\
\hline \multirow[t]{15}{*}{-} & CP $65-357$ (c) & Louisiana; Ranchillos \\
\hline & TUCCP 77-42 (c) & El Naranjo; Louisiana; Simoca \\
\hline & LCP $85-384(\mathrm{c})$ & Los Córdoba; Santa Ana \\
\hline & & $\begin{array}{l}\text { Cruz Alta (3); Delfín Gallo (2); El Timbó; Los Ralos; Louisiana; Acheral, Alberdi, La Florida, Leales, León } \\
\text { Rougés, Los Sarmiento; Padilla; Santa Lucía; Sargento Moyano; Taruca Pampa; Cevil Pozo; La Banda; Lules; } \\
\text { Mercedes; San Pablo; Las Talitas }\end{array}$ \\
\hline & TUC 03-66 (cl) & Santa Ana; Cevil Pozo \\
\hline & TUC 04-33 (cl) & Santa Ana \\
\hline & TUC $03-55(\mathrm{cl})$ & \\
\hline & TUC 04-68 (cl) & \\
\hline & TUC 95-37 (c) & \\
\hline & TUC $97-8(\mathrm{c})$ & Cevil Pozo \\
\hline & & HOCP $02-625(\mathrm{p})$ \\
\hline & TUC $95-30(p)$ & \\
\hline & TUC 96-24 (p) & \\
\hline & TUC 99-125 (p) & \\
\hline & TUC 99-132(p) & Las Talitas \\
\hline \multirow[t]{3}{*}{+} & LCP 85-384 (c) & Louisiana; Bella Vista; Cevil Pozo; Fronterita (2) \\
\hline & TUC 97-4 (p) & Las Talitas \\
\hline & TUC 97-8 (c) & Santa Ana \\
\hline \multicolumn{3}{|l|}{ Symptomatic } \\
\hline \multirow[t]{4}{*}{-} & TUC 95-30 (p) & \\
\hline & TUC 96-24 (p) & \\
\hline & TUC $99-125(\mathrm{p})$ & \\
\hline & TUC 99-132 (p) & Las Talitas \\
\hline \multirow[t]{2}{*}{+} & TUC 95-24 (p) & \\
\hline & TUC 97-4 (p) & Las Talitas \\
\hline
\end{tabular}

\footnotetext{
${ }^{a}$ Virus detection by reverse-transcription polymerase chain reaction with specific primers.

${ }^{\mathrm{b}}$ Abbreviations: $\mathrm{c}=$ commercial variety, $\mathrm{cl}=$ advanced clones, and $\mathrm{p}=$ parent at the breeding program.

${ }^{c}$ Numbers in parentheses indicate number of samples more than one.
} 
SCYLV genotype identification. Only samples that tested positive for SCYLV were used to identify the viral genotypes by RTPCR with primers that amplified a specific genome fragment from each genotype (BRA-PER: F: AACTGCTGCGTCAGGCCCA and R: GACGAGCTTGCGTTGTTTTTCT; CUB: F: GTGCTTCTC CCGGCGGTTCACT and R: ATTCGAGAACAACCTCCGCCTC; and REU: F: CAAGCTTCTAGCGGGAATC and R: CAGTTG CTCAATGCTCCACG). Reaction was performed as described by Abu Ahmad et al. (2), with modifications. First-strand cDNA (4.5$\mu \mathrm{l}$ final volume) was synthesized using $2 \mu \mathrm{l}$ of total plant nucleic acid and $10 \mu \mathrm{M}$ reverse primer as the initial primer. The mixture was boiled at $95^{\circ} \mathrm{C}$ for $5 \mathrm{~min}$ and quenched on ice for $3 \mathrm{~min}$. RT solution consisting of $1 \times$ RT-PCR buffer, $0.33 \mathrm{mM}$ dNTPs (Amersham Biosciences), 1.3 U of RNase inhibitor (Promega Corp.), and $13 \mathrm{U}$ of M-MLV (Promega Corp.), was performed at $42^{\circ} \mathrm{C}$ for 30 min. Amplification was carried out in a $20-\mu$ reaction mix consisting of $7 \mu \mathrm{l}$ of RT reaction solution, 1× PCR buffer (Promega Corp.), $1.3 \mathrm{mM} \mathrm{MgCl} 2$ (Promega Corp.), $75 \mu \mathrm{M}$ dNTPs (Amersham Biosciences), $0.3 \mu \mathrm{M}$ forward primer, $1 \mathrm{U}$ of Taq DNA polymerase (Promega Corp.), and DEPC water (USB Corp.) to final volume. PCR cycling parameters were 1 cycle at $95^{\circ} \mathrm{C}(5 \mathrm{~min})$, $61^{\circ} \mathrm{C}$ for BRA-PER genotype, $56^{\circ} \mathrm{C}$ for CUB and $51^{\circ} \mathrm{C}$ for REU $(1$ $\mathrm{min}), 72^{\circ} \mathrm{C}(10 \mathrm{~min})$, and $94^{\circ} \mathrm{C}(1 \mathrm{~min})$; and 40 cycles at $94^{\circ} \mathrm{C}(15$ s), $61^{\circ} \mathrm{C}$ for BRA-PER genotype, $56^{\circ} \mathrm{C}$ for CUB and $51{ }^{\circ} \mathrm{C}$ for REU (15 s), and $72^{\circ} \mathrm{C}(30 \mathrm{~s})$; and a final elongation at $72^{\circ} \mathrm{C}$ for 5 min. The reaction mixture was analyzed on $1.5 \%$ agarose gel stained with ethidium bromide and visualized under UV light. The amplification product of SCYLV genotypes BRA-PER, CUB, and REU have expected sizes of 362, 450, and $905 \mathrm{bp}$, respectively.

Cloning and sequencing of the RT-PCR product from SCYLV isolates. Three RT-PCR products belonging to the virus $\mathrm{CP}$ gene of symptomatic samples were gel purified using the GE Healthcare Illustra GFX PCR DNA and Gel Band Purification kit (Life Sciences), cloned into the pGEM-T Easy vector (Promega Corp.) following the manufacturer's protocol, and transformed into Escherichia coli DH5 $\alpha$ cells. Recombinant pGEM-T Easy clones were chosen based on EcoRI (G/AATTC; Promega Corp.) restriction analysis. Three clones of each amplified fragment were sequenced on an automated DNA Sequencer (Abi 3130xl Genetic
Analyzer; Hitachi) using SP6 (5'-CATACGATTTAGGTGACA CTATAG-3') and T7 (5'-TAATACGACTCACTATAGGG-3') primers. Nucleotide sequences obtained in both directions were used to create the partial sequence of the SCYLV CP gene. Sequences obtained were deposited in GenBank. The nucleotide identity was

Table 4. Summary results of the survey for Sugarcane yellow leaf virus (SCYLV)

\begin{tabular}{lccccc}
\hline & \multicolumn{5}{c}{ SCYLV $^{\mathbf{a}}$} \\
\cline { 2 - 3 } \cline { 5 - 6 } Samples & \multicolumn{2}{c}{ Asymptomatic } & & \multicolumn{2}{c}{ Symptomatic } \\
\cline { 2 - 3 } \cline { 5 - 6 } & - & + & & - & + \\
\hline Commercial varieties & 53 & 16 & & 0 & 3 \\
Breeding program & & & & & \\
$\quad$ Parents & 5 & 1 & & 4 & 2 \\
Advanced clones & 58 & 7 & & 0 & 0 \\
Total & 116 & 24 & & 4 & 5 \\
\hline
\end{tabular}

a Symbols: + or - indicate SCYLV detected or undetected, respectively, by reverse-transcription polymerase chain reaction.

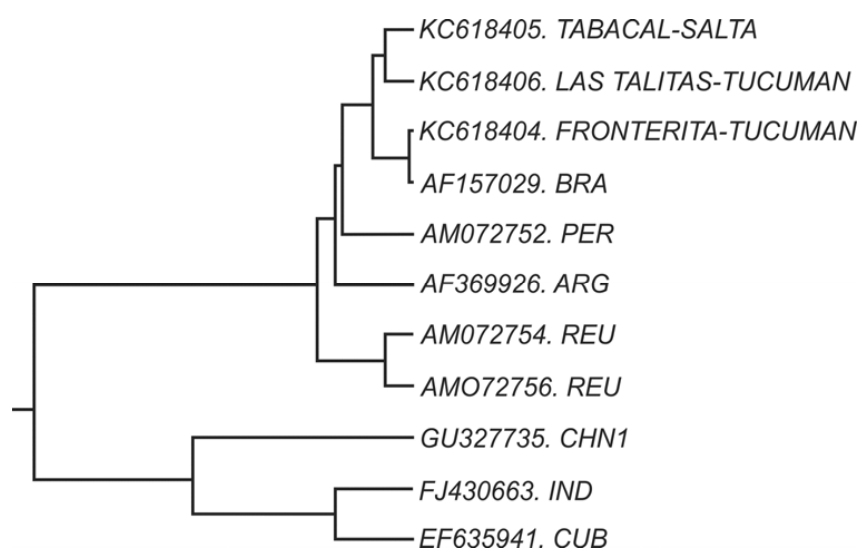

Fig. 1. Phylogenetic tree of Sugarcane yellow leaf virus based on the coat protein gene (ORF3) nucleotide sequences constructed by the neighbor-joining method with 1,000 bootstrap replications.

Table 2. Detection of Sugarcane yellow leaf virus by reverse-transcription polymerase chain reaction in asymptomatic leaf samples of diverse sugarcane genotypes, collected in 2012 from six locations in Tucumán, Argentina, where the local breeding program is conducted

\begin{tabular}{|c|c|c|c|c|c|c|}
\hline \multirow[b]{2}{*}{ Sugarcane genotypes } & \multicolumn{6}{|c|}{ Location } \\
\hline & Fronterita & Ingas & La Banda & Mercedes & Palá-Palá & Los Córdoba \\
\hline \multicolumn{7}{|l|}{ Commercial variety } \\
\hline CP $65-357$ & - & - & - & + & + & - \\
\hline RA 87-3 & + & + & + & - & + & - \\
\hline TUC $95-10$ & + & + & - & - & - & - \\
\hline TUCCP 77-42 & - & - & - & + & + & - \\
\hline LCP 85-384 & _- & - & - & - & - & - \\
\hline \multicolumn{7}{|l|}{ Advanced clones } \\
\hline TUC $00-28$ & + & - & - & - & + & - \\
\hline TUC $00-58$ & - & - & - & - & + & - \\
\hline TUC 02-19 & - & - & + & - & - & - \\
\hline TUC $03-33$ & + & + & + & - & - & - \\
\hline TUC $02-35$ & - & - & - & - & - & - \\
\hline TUC $02-58$ & - & - & - & - & - & _- \\
\hline TUC 02-64 & - & - & - & - & - & - \\
\hline TUC $02-71$ & - & - & - & - & - & _- \\
\hline TUC 03-1 & - & - & - & - & - & - \\
\hline TUC 03-22 & - & - & - & - & - & - \\
\hline
\end{tabular}

Table 3. Symptomatic leaf samples collected in 2012, positive for Sugarcane yellow leaf virus by RT-PCR and sequences characterized in this study

\begin{tabular}{lllcc}
\hline Commercial sugarcane genotypes & Province & Location & GenBank accession number & Symptoms \\
\hline LCP 85-384 & Tucumán & Las Talitas & KC618406 & Yellowing of the midrib \\
TUC 89-28 & Tucumán & Fronterita & KC618404 & Yellowing of the midrib \\
NA 02-2320 & Salta & Tabacal & KC618405 & Yellowing of the midrib \\
\hline
\end{tabular}

${ }^{a}$ GenBank accession numbers newly reported here. 
conducted using the DNAMan software (Lynnon BioSoft). The regions of $350 \mathrm{bp}$ from the $\mathrm{CP}$ encoding region were aligned and their phylogeny determined by ClustalX (26) using the neighborjoining option with a bootstrap analysis of 1,000 random replications. Sequences from GenBank were also included in the analysis.

Histological, in situ observation of starch. Leaves +1 from symptomatic and asymptomatic samples, with and without virus determined by RT-PCR, were fixed in formol-acetic acid-ethyl alcohol. Transversal sections from midribs and leaf blades were severed with a razor blade for starch staining (15). Sections were incubated in iodine solution $(1 \mathrm{~g}$ of potassium iodine and $1 \mathrm{~g}$ of iodine in $100 \mathrm{ml}$ water) for $10 \mathrm{~min}$ and mounted on a slide, a drop of glycerin was added, and samples were covered with a coverslip for observation under a light microscope (Leica DM500).

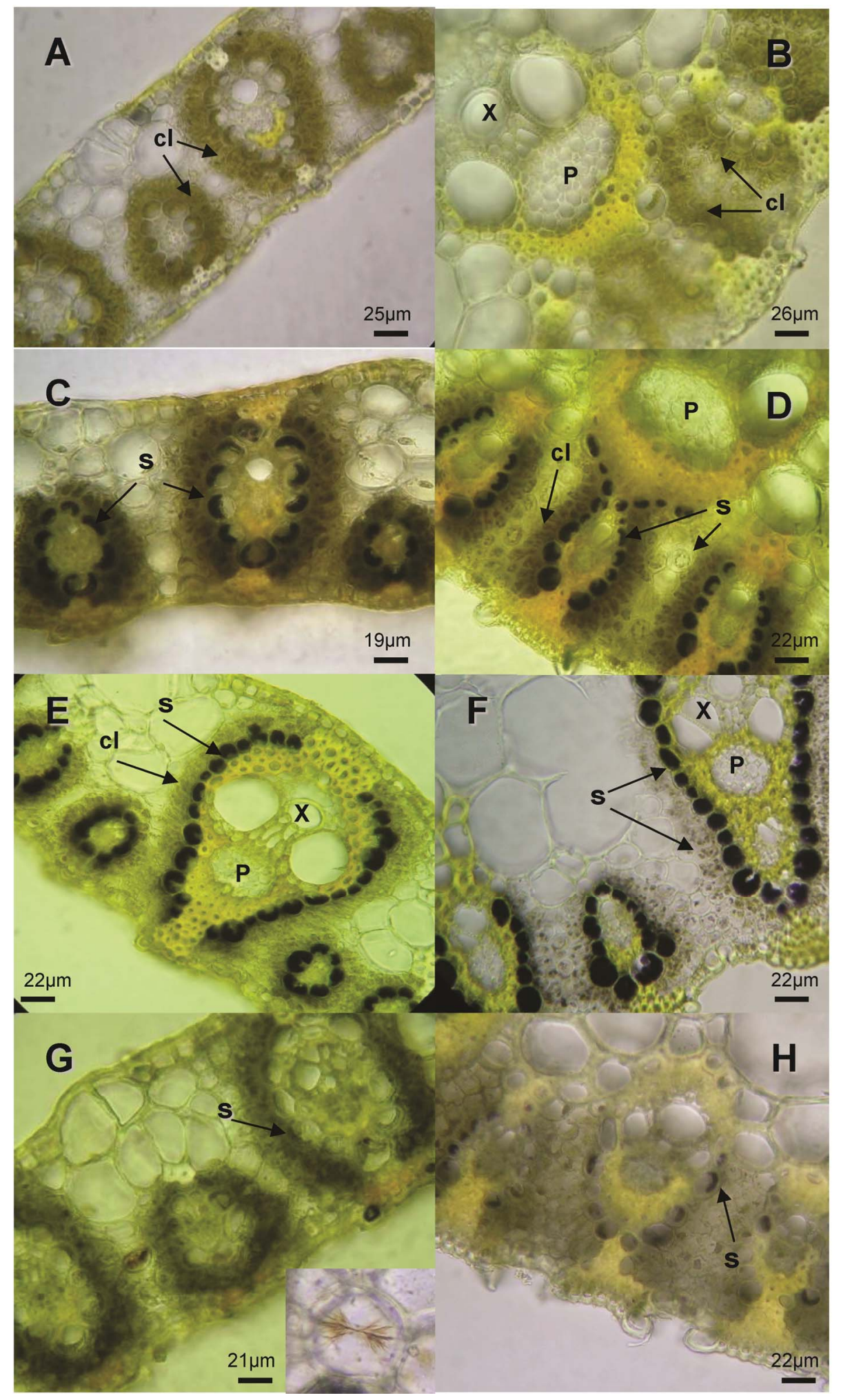

Fig. 2. In situ localization of starch in virus-infected and virus-free leaf samples from sugarcane. Transversal sections from leaf blade and midribs stained with iodine solution. A and B, Asymptomatic samples, Sugarcane yellow leaf virus (SCYLV) negative by reverse-transcription polymerase chain reaction (RT-PCR). C and D, Asymptomatic samples, SCYLV positive by RT-PCR. E and F, Symptomatic samples, SCYLV positive by RT-PCR. G and H, Symptomatic samples, SCYLV negative by RT-PCR, with crystal detail. Symbols: $s=$ starch, $X=$ xylem,$P=$ phloem, and $c l=$ chlorenchyma. 


\section{Results}

SCYLV detection. SCYLV was detected by RT-PCR in 29 samples, including the Salta sample, out of 149 plants collected in 2011 and 2012 (Tables 1-3). The virus was evenly distributed within the sugarcane-producing area, as could be seen from its detection in most of the Tucumán locations sampled. This conclusion was supported by the fact that the virus was found in five of the six locations where the local breeding program is maintained (Table 2). These locations represented all different agroecological regions where sugarcane is grown. On the other hand, it must be pointed out that $66 \%$ of the positive samples belonged to commercial varieties (Table 4). Of the five commercial varieties sampled in 2012 at six locations, RA 87-3 was the most affected (Table 2).

Symptoms versus virus presence correlation. SCYLV was detected in five out of the nine samples showing intense yellowing of the midrib, symptoms associated with virus presence, and in 24 of 140 symptomless plants. It should be emphasized that 4 of the 120 samples(3.33\%) in which virus could not be detected by RT-PCR showed disease symptoms (Table 4). However, a statistically significant correlation, low and directly proportional $(\mathrm{r}(\mathrm{phi})=0.23, P$ $\leq 0.05$ ), was found between the presence of the SCYLV and characteristic disease symptoms.

Genotyping of SCYLV in sugarcane-growing locations. The SCYLV genotypes of the 29 infected leaf samples, as detected by RT-PCR, isolated from 30 different sugarcane-growing locations in Tucumán and 1 location in Salta, were determined by RT-PCR amplifications with three different primer pairs, as described previously. BRA-PER was the only genotype detected, indicating its high prevalence in local commercial varieties, advanced breeding clones, and parents in the EEAOC breeding program. The BRAPER genotype is by far the most predominant virus type throughout the world. as previous reports have been showing.

Phylogenetic analysis. In order to determine whether there was any genetic diversity among virus isolates, three RT-PCR fragments belonging to the $\mathrm{CP}$ gene were purified, cloned, sequenced, and deposited in the GenBank database (Table 3). A phylogenetic analysis was conducted including the new sequences and nine reported partial $\mathrm{CP}$ gene sequences $(350 \mathrm{bp})$ belonging to genotypes CHN1, REU, PER, CUB, BRA, and IND. Although the CP gene comparisons should not be used as a sole criterion to differentiate among SCYLV genotypes, due to being highly conserved and, for that reason, employed to detect the virus, the phylogenetic tree revealed some genetic diversity and showed clustering among samples (Fig. 1). As expected following the previous genotype determination (see above), all three sequences grouped together with BRA and PER genotypes.

The phylogenetic analysis revealed that the new SCYLV isolates described here were most closely related to viruses isolated in Brazil (AF157029), Peru (AM072752), Reunion Island (AM072756 and AM072754), and Argentina (AF369926), forming a single cluster. In a second cluster, virus samples from Cuba (EF635941), China (GU327735), and India (FJ430663) grouped together (Fig. 1).

From the phylogenetic analysis, it can be concluded that the new isolates are not grouped according to their geographical origin. Two of them (KC618405 and KC618406) from Tabacal-Salta and Las Talitas-Tucumán (402.25 km of distance between them) were clustered in the same branch showing a nucleotide sequence identity of $99.7 \%$, despite Salta being a different geographical, agroecological, and production area. The third isolate (KC618404) from Fronterita-Tucumán showed $100 \%$ identity with virus sequence AF157029, isolated in Florida (Fig. 1).

In situ localization of starch. Starch accumulation in bundle sheath and mesophyll cells due to impaired carbohydrate export has been correlated with SCYLV infection previously $(28,29)$. Therefore, we studied starch accumulation in leaves showing disease symptoms where the virus could be detected, in symptom leaves where no virus could be detected, as well as in symptomless plants showing presence and absence of the virus. In all SCYLV- positive disease symptomatic samples, high concentrations of starch in mesophyll cells of both leaf blade and midrib and markedly more stained in the bundle sheath were detected (Fig. 2E and F). Similar results were found in virus-positive but disease-asymptomatic samples, where high levels of starch were detected in bundle sheath cells. However, these samples had chlorenchymatic tissue with more chloroplasts than leaves isolated from plants showing disease symptoms (Fig. 2C and D).

Disease asymptomatic samples, carrying no virus as determined by negative RT-PCR, had chlorenchymatic tissue with numerous chloroplasts and no detectable levels of starch in the bundle sheath cells (Fig. 2A and B). On the other hand, symptomatic samples where no virus could be detected by RT-PCR showed very low but detectable levels of starch in chlorophyll parenchymal cells (Fig. $2 \mathrm{G}$ and $\mathrm{H}$ ), and crystal formation was present.

\section{Discussion}

SCYLV has been detected in most sugarcane-producing countries around the world; however, very little information exists on the incidence and distribution of the disease in Argentina. The present study showed that this virus is much more widespread in Tucuman, the main production area, than expected based on visual disease symptoms, and that as much as $83 \%$ of the positive samples were asymptomatic. The virus was detected in both commercial cultivars and advanced breeding clones but there were also several of them where the virus was not detected. This latter result implies that the germplasm could contain useful genetic resistance sources, especially in those clones and varieties monitored at six different locations that did not show symptoms or detectable levels of the virus (Table 2). On the other hand, many of the susceptible genotypes were not infected in all the localities sampled. For instance, only 6 of the 38 samples collected of the LCP 85-384 variety, which is known to be susceptible to the disease (22), were positive. This may be explained by a low incidence of the virus or low levels of the vector population. Further studies need to be conducted to determine the presence and distribution of the aphid vector in this sugarcane-growing area.

A low but significant statistical correlation between symptoms and virus detection was found, because SCYLV was detected by RT-PCR in $5(55 \%)$ symptomatic and 24 (17\%) symptomless plant samples. Lehrer and Komor (27), when studying sugarcane fields in Hawaii, also observed a clear relationship. However, this positive correlation is still controversial. Contrary to the previous studies mentioned, Aljanabi et al. (4) and Smith et al. (38) found a nonsignificant correlation coefficient. This could be explained by the high sensitivity of the RT-PCR assay, which can detect low titers of the virus in latent infected canes. In fact, Lehrer et al. (28) suggested that the nonsymptomatic stage seems to be the most common epidemiological state for this viral pathogen, because it is waiting for suitable growth conditions in order to spread and induce proper disease symptoms. It has been reported that stress conditions such as cold and water deficit tend to favor disease symptom development (4). In addition, leaf yellowing in sugarcane is not a specific response to SCYLV because several biotic and abiotic factors can cause very similar symptoms $(6,11,38)$. For these reasons, symptoms could not be a diagnostically reliable indicator for the presence of the virus.

Genotypic analysis has identified seven SCYLV genotypes which sometimes coexist in the same sugarcane-growing area or in the same cultivar. Based on their geographical origin, they have been placed into three continental groups: Asian (CHN1 and IND), American (BRA, CUB, HAW, and PER), and African (REU) $(2,9)$. Abu Ahmad et al. (2) studied the geographical distribution of four SCYLV genotypes (BRA, CUB, PER, and REU) and concluded that they are not distributed evenly throughout the world. The BRA-PER genotype was the most widespread, because it was present in 18 locations in Africa, Asia, and America, whereas CUB and REU genotypes have only been found in some locations: Brazil, Colombia, Cuba, and Guadeloupe for CUB and Guadeloupe, Mauritius, and Reunion Island for REU (2). In addition, the new 
HAW, CHN1, and IND genotypes have thus far only appeared in Hawaii, China, and India, respectively $(9,42)$. This study revealed, by using specific RT-PCR, that the BRA-PER genotype was the only one found in all positive sugarcane samples, in agreement with a previous study in Argentina conducted by Cafrune et al. (7). However, no virus incidence or distribution was determined in the cited study (7). Three of the positive samples were sequenced and the phylogenetic analysis of the CP gene showed that all three sequences grouped with previously reported BRA and PER genotypes. Although, the $\mathrm{CP}$ gene sequence was considered to be a bad candidate for genotype studies in order to differentiate among SCYLV isolates due to its high conservation $(9,42)$, in our study, the differences in sequence of this gene enabled us to cluster strains as well as distinguish among individual isolates. In accordance with our results, Viswanathan et al. (41) also detected variability between Indian genotypes and virus isolates from other geographical sites, analyzing the $\mathrm{CP}$ gene.

The spread of BRA-PER genotype in Tucumán and Salta Provinces in the North of Argentina could be explained by the set up of the local breeding program, where genetic resources have been introduced from other breeding programs from abroad for a long time, especially when sugarcane YL was unknown (2) or when efficient detection tools were still not available (20). In addition, Argentina has only had a functional 2-year quarantine for imported sugarcane varieties together with molecular disease testing since 2005. Results pointed out that, in order to prevent the introduction of new pathogens or new strains of the existing ones, quarantines and efficient diagnostic protocols need to be implemented (12). It seems that such an introduction might have happened, because the new isolates reported here, including the one from Salta where the quarantine facility is located, grouped with the AF157029 isolate from the United States, the predominant supplier of new germplasm in Tucumán (33).

To minimize potential sugarcane yield loss caused by SCYLV infection, growers should plant seed cane that is free of the virus. The only reported method to obtain truly virus-free plants was found to be the use of plants derived from meristem tissue culture $(8,18)$. For that reason, the EEAOC has been working on a "Vitroplantas" project for the last decade, aimed at producing healthy plant material derived from in vitro meristem cultures for seed cane production. On average, 90,000 sugarcane seedlings of the main sugarcane varieties are produced annually to guarantee seedlings with high phytosanitary quality and genetic purity. The sanitation of the plant material is achieved through in vitro culture of apical meristems from specific donor plants, previously hydroheat-treated and grown under natural light conditions in greenhouses with anti-aphid screen during a maximum of 3 years. To ensure a healthy and vigorous product, both meristem donor plants and micropropagated seedlings are evaluated constantly by different molecular diagnosis methods. By implementing this plant seed production system, disease incidences have significantly decreased in the sugarcane fields in Tucumán (17). As a direct result of this research, SCYLV detection in the Vitroplantas program has been recently incorporated as a standard procedure.

In situ localization and determination of starch accumulation in SCYLV-positive plant samples, both symptomatic and symptomless, showed high concentrations in bundle sheath cells. The virus presence affects carbon assimilation and plant cell metabolism due to structural changes in the chloroplasts associated with increase of respiration, reduction of photosynthesis, changes in the ratio of hexose to sucrose, and high levels of starch. Additionally, the movement proteins increase the permeability of plasmodesmata to virus particles as well as decrease the transport of sugars from source to sink tissues, promoting nonstructural carbohydrate accumulation in the leaf $(24,31)$. Normally, all transitory starch is degraded and mobilized from the leaf to sink tissue but presence of virus can impede the export of assimilates and, thereby, generate starch accumulation in the leaves (28). Such changes in SCYLVinfected plants indicate that they are suffering from infection even when visual disease symptoms are absent. Our results also showed that asymptomatic samples, where virus was detected, contained chlorenchymatic tissue with higher numbers of chloroplasts than the virus-positive symptomatic samples where a reduced number and small size of the chloroplasts were observed. Asymptomatic samples probably would be in an early stage of infection, where chloroplasts have not yet been altered structurally and functionally; therefore, plants would still be showing a green color and healthy appearance. Thus, when the virus infection has progressed, chloroplasts are disrupted and lose their coloration, and yellowing symptoms are visually observed. These results are in accordance with Goodman et al. (21) and Yan et al. (43), who proposed that the expression of viral proteins causes changes in chlorophyll synthesis and ruptures in the ultrastructure and function of chloroplasts. Although other studies have found high starch accumulation in SCYLV-infected plants compared with virus-free samples and susceptible versus resistant SCYLV plants, respectively $(28,29)$, and taking into account the available information that we found, this would be the first report where positive samples identified by RT-PCR, symptomatic and asymptomatic, were compared.

On the other hand, the four symptomatic samples that were found to be virus negatives by RT-PCR had several crystals present in chlorophyll parenchyma cells. Although, in this work, no analysis to determine the composition of the crystals was performed, according to the morphological descriptions given by Vincent and Nakata (40), it is possible that these crystals are of oxalate. These crystals may be associated with phytoplasma infection, as was reported by Poghosyan and Lebsky (34). Previous studies on etiology of sugarcane YL syndrome in Mauritius (4), Hawaii (18), and Cuba (5) concluded that either SCYLV or SCYP or their combinations are associated with development of disease symptoms. Therefore, additional tests are currently being conducted to identify the possible presence of SCYLP in those samples.

\section{Acknowledgments}

We thank M. LaO Echeverría (INICA) for providing us with positive controls; M. B. García and S. Ostengo for the statistical analysis; and EEAOC, CONICET, and UNT for their financial support. L. D. Ploper and A. P. Castagnaro are CONICET members and R. P. Bertani is a CONICET fellow.

\section{Literature Cited}

1. Abu Ahmad, Y., Rassaby, L., Royer, M., Borg, Z., Braithwaite, K. S., Mirkov, T. E., Irey, M. S., Perrier, X., Smith, G. R., and Rott, P. 2006. Yellow leaf of sugarcane is caused by at least three different genotypes of Sugarcane yellow leaf virus, one of which predominates on the Island of Réunion. Arch. Virol. 151:1355-1371.

2. Abu Ahmad, Y., Royer, M., Daugrois, J. H., Costet, L., Lett, J. M., Victoria, J. I., Girard, J. C., and Rott, P. 2006. Geographical distribution of four Sugarcane yellow leaf virus genotypes. Plant Dis. 90:1156-1160.

3. Aljanabi, S. M., Forget, L., and Dookun, A. 1999. An improved and rapid protocol for the isolation of polysaccharide and polyphenol-free sugarcane DNA. Plant Mol. Biol. Rep. 17:1-8.

4. Aljanabi, S. M., Parmessur, Y., Moutia, Y., Saumtally, S., and Dookun, A. 2001. Further evidence of the association of a phytoplasma and a virus with yellow leaf syndrome in sugarcane. Plant Pathol. 50:628-636.

5. Arocha, Y., López, M., Fernández, M., Piñol, B., Horta, D., Peralta, E. L., Almeida, R. Carvajal, O., Picornell, S., Wilson, M. R., and Jones, P. 2005.Transmission of a sugarcane yellow leaf phytoplasma by the delphacid planthopper Saccharosydne saccharivora, a new vector of sugarcane yellow leaf syndrome Plant Pathol. 54:634- 642.

6. Borth, W., Hu, J. S., and Schenk, S. 1994. Double-stranded RNA associated with sugarcane yellow leaf syndrome. Sugar Cane 3:5-8.

7. Cafrune, E. E., Pérez Gómez, S., Conci, V. C., and Rago, A. 2012. Identificación de Sugarcane yellow leaf virus afectando caña de azúcar en Argentina. Libro de resúmenes XVIII Reunión Técnica Nacional de la Caña de azúcar 69-72.

8. Chatenet, M., Delage, C., Ripolles, M., Irey, M., Lockhart, B. E. L., and Rott, P. 2001. Detection of Sugarcane yellow leaf virus in quarantine and production of virus-free sugarcane by apical meristem culture. Plant Dis. 85:1177-1180.

9. Chinnaraja, C., Viswanathan, R., Karuppaiah, R., Bagyalakshmi, K., Malathi, P., and Parameswari, B. 2013. Complete genome characterization of Sugarcane yellow leaf virus from India: evidence for RNA recombination. Eur. J. Plant Pathol. 135:335-349.

10. Comstock, J. C., Irey, M. S., Lockhart, B. E. L., and Wang, Z. K. 1998. Incidence of yellow leaf syndrome in CP cultivars based on polymerase chain reaction and serological techniques. Sugar Cane 4:21-24.

11. Comstock, J. C., Irvine, J. E., and Miller, J. D. 1994. Yellow leaf syndrome 
appears on the United States mainland. Int. Sugar J. 56:33-35.

12. Croft, B. J., Piggin, C. M., Wallis, E. S., and Hogarth, D. M. 1996. Sugarcane germplasm conservation and exchange. In: Proc. Aust. Cent. Int. Agric. Res. Canberra 67.

13. Cronjé, C. P. R., and Bailey, R. A. 1999. Association of phytoplasmas with yellow leaf syndrome of sugarcane. Pages 373-380 in: Proc. Int. Soc. Sugar Cane Technol. Congr.

14. Cronjé, P., Tymon, A., Jones, P., and Bailey, R. 1998. Association of a phytoplasma with a yellow leaf syndrome of sugarcane in Africa. Ann. Appl. Biol. 133:177-186.

15. D’Ambrogio de Argüeso, A. 1986. Manual de Técnicas en Histología Vegetal. Hemisferio Sur, Buenos Aires, Argentina.

16. ElSayed, A. I., Weig, A. R., and Komor, E. 2011. Molecular characterization of Hawaiian Sugarcane yellow virus leaf genotypes and their phylogenetic relationship to strains from other sugarcane-growing countries. Eur. J. Plant Pathol. 129:399-412.

17. Filippone, M. P., Perera, M. F., Salgado, M., García, M. G., Velicce, G. R., and Castagnaro, A. P. 2010. Diagnóstico molecular de enfermedades sistémicas de la caña de azúcar en Argentina: ajuste metodológico y aplicaciones. Rev. Ind. Agríc. Tucumán 87:1-7.

18. Fitch, M. M. M., Lehrer, A. T., Komor, E., and Moore, P. H. 2001. Elimination of Sugarcane yellow leaf virus from infected sugarcane plants by meristem tip culture visualized by tissue blot immunoassay. Plant Pathol. 50:676-680.

19. Fontana, P. D., Rago, A. R., Fontana, C. A., Vignolo, G. M., Cocconcelli, P. S., and Mariotti, J. A. 2013. Isolation and genetic characterization of Acidovorax avenae from red stripe infected sugarcane in Northwestern Argentina. Eur. J. Plant Pathol. Online publication. doi:10.1007/s10658-013-0263-y

20. Girard, J. C., Fernandez, E., Daugrois, J. H., Roques, D., Roumagnac, P., and Rott, P. 2010. Genetic diversity of Sugarcane yellow leaf virus in a sugarcane selection plot in Guadeloupe (FWI). Proc. Int. Soc. Sugar Cane Technol. 27:1-9.

21. Goodman, R. N., Kiraly, Z., and Wood, K. R. 1986. The Biochemistry and Physiology of Plant Disease. University of Missouri Press, Columbia.

22. Grisham, M. P., Eggleston, G., Hoy, J. W., and Viatorl, R. P. 2009. The effect of Sugarcane yellow leaf virus infection on yield of sugarcane in Louisiana. Sugar Cane Int. 27:91-94.

23. Grisham, M. P., Pan, Y. B., Legendre, B. L., Godshall, M. A., and Eggleston, G. 2001. Effect of Sugarcane yellow leaf virus on sugarcane yield and juice quality. Proc. Int. Soc. Sugar Cane Technol. Congress 24:434-438.

24. Herbers, K., Takahata, Y., Melzer, M., Mock, H.-P., Hajirezaei, M., and Sonnewald, U. 2000. Regulation of carbohydrate partitioning during the interaction of Potato virus $Y$ with tobacco. Mol. Plant Pathol. 1:51-59.

25. Joomun, N., Parmessur, Y., Antoine, M., and Dookun-Saumtally, A. 2012. Screening for Sugarcane yellow leaf virus in quarantine in Mauritius. In: 10th ISSCT Plant Pathol. Workshop, Nanning, China.

26. Larkin, M. A., Blackshields, G., Brown, N. P., Chenna, R., McGettigan, P. A., McWilliam, H., Valentin, F., Wallace, I. M., Wilm, A., Lopez, R., Thompson, J. D., Gibson, T. J., and Higgins, D. G. 2007. Clustal W and Clustal X version 2.0. Bioinformatics 23:2947-2948.

27. Lehrer, A. T., and Komor, E. 2008. Symptom expression of yellow leaf disease in sugarcane cultivars with different degrees of infection by Sugarcane yellow leaf virus. Plant Pathol. 57:178-189.
28. Lehrer, A. T., Moorec, P. H., and Komor, E. 2007. Impact of Sugarcane yellow leaf virus (ScYLV) on the carbohydrate status of sugarcane: comparison of virus-free plants with symptomatic and asymptomatic virus-infected plants. Physiol. Mol. Plant Pathol. 70:180-188.

29. Lehrer, A., Shih-Long, Y., Fontaniella, B., El Sayed, A., and Komor, E. 2010. Carbohydrate composition of sugarcane cultivars that are resistant or susceptible to Sugarcane yellow leaf virus. J. Genet. Plant Pathol. 76:62-68.

30. Lockhart, B. E. L, and Cronjé, C. P. R. 2000. Yellow leaf syndrome. Pages 291-295 in: A Guide to Sugarcane Diseases. P. Rott, R. A. Bailey, J. C. Comstock, B. J. Croft, and A. S. Saumtally, eds. La Librairie du Cirad, Montpellier, France.

31. Lucas, W. J., Ding, B., and van der Schoot, C. 1993. Plasmodesmata and the supracellular nature of plants. New Phytol. 125:435-476.

32. Moonan, F., and Mirkov, T. E. 2002. Analyses of the genotypic diversity among North, South, and Central American isolates of Sugarcane yellow leaf virus: evidence for Colombian origins and for intraspecific spatial phylogenetic variation. J. Virol. 76:1339-1348.

33. Perera, M. F., Arias, M. E., Costilla, D., Luque, A. C., García, M. B Cuenya, M. I., Racedo, J., Ostengo, S., Filippone, M. P., and Castagnaro, A. P. 2012. Evaluation of genetic diversity in sugarcane cultivars based on DNA markers and morphological traits. Euphytica 185(3):491-510. doi: 10.1007/s10681-012-0661-9.

34. Poghosyan, A., and Lebsky, V. 2006. Microscopía electrónica de barrido: una herramienta esencial para el diagnóstico de fitoplasmas. Oral presentation: VIII Congreso Nacional Asociación Mexicana de Microscopía. Acapulco, Guerrero México.

35. Ramallo, J., and Ploper, L. D. 1998. ¿Síntomas de amarillamiento en cañaverales de Tucumán? Avance Agroind. 72:16-18.

36. Rott, P., Mirkov, T. E., Schenck, S., and Girard, J. C. 2008. Recent advances in research on Sugarcane yellow leaf virus, the causal agent of sugarcane yellow leaf. Sugar Cane Int. 26:18-27.

37. Scagliusi, S. M., and Lockhart, B. E. L. 2000. Transmission, characterization, and serology of a luteovirus associated with yellow leaf syndrome of sugarcane. Phytopathology 90:120-124.

38. Smith, G. R., Braithwaite, K. S., and Cronjé, C. P. R. 2001. The viral and phytoplasma forms of yellow leaf syndrome of sugarcane. Proc. Int. Soc. Sugar Cane Technol. Congress 24:614-617.

39. Vega, J., Scagliusi, S. M. M., and Ulian, E. C. 1997. Sugarcane yellow leaf disease in Brazil: evidence of association with a luteovirus. Plant Dis. 81:21-26

40. Vincent, F., and Nakata, P. 2005. Calcium oxalate in plants: formation and function. Annu. Rev. Plant. Biol. 56:41-71.

41. Viswanathan, R., Balamuralikrishnan, M., and Karuppaiah, R. 2008. Identification of three genotypes of Sugarcane yellow leaf virus causing yellow leaf disease from India and their molecular characterization. Virus Genes 37:368-379.

42. Wang, M. Q., and Zhou, G. H. 2010. A near complete genome sequence of a distinct isolate of Sugarcane yellow leaf virus from China, representing a sixth new genotype. Virus Genes 41:268-272.

43. Yan, S. L., Lehrer, A.T., Hajirezaei, M.R., Springer, A., and Komor, E. 2009. Modulation of carbohydrate metabolism and chloroplast structure in sugarcane leaves which were infected by Sugarcane yellow leaf virus (SCYLV). Physiol. Mol. Plant Pathol. 73:78-87. 